\title{
Foraging Rhythm of Honeybees Apis mellifera in Ismailia, Egypt
}

\author{
Reem M. Abdel-Galel, Shereen M. Elbanna, Fayez M. Semida \\ Zoology Department, Faculty of Science, Suez Canal University, Ismailia; Egypt
}

\begin{abstract}

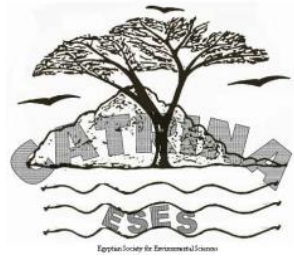

Most of the human food resources depend on honeybees; they are the most efficient pollinators that contribute to our ecosystem stability, biodiversity and crop productivity. Honeybees' foraging behavior is affected by many environmental factors. Daytime, ambient temperature and food availability (nectar and pollen) are the most influencing factors on foraging behavior. Many ecological studies were done to study this behavior, in addition to its seasonal and monthly abundance. In this study, honeybees' foraging activities, as well as their seasonal and monthly abundance were studied and evaluated. The study was run during the period of 12/2017-11/2018. All beekeeping managements were provided to retain the colony in good condition during the period of the experiment. The obtained results revealed that honeybees have a bimodal daily foraging activity pattern with morning and afternoon peaks. The daily activity pattern of honeybees showed a significant correlation with the measured temperature. Meanwhile, the seasonal abundance of forager bees changed significantly among different seasons with the highest abundance peak during spring. Results also suggest that the honeybees' activity had a microclimatic window of opportunity for ambient temperatures within which foraging flight can be continued, where their forage temperature was fallen within the range of $20^{\circ} \mathrm{C}$ to $28^{\circ} \mathrm{C}$.
\end{abstract}

Keywords: Apis mellifera, Foraging, Honeybee, Rhythm

\section{INTRODUCTION}

Foraging is the link between honeybee colony and their exterior environment. Social insect forager does not seek food in the environment for individual life, but for colony energy reserves. Thus it is not surprising that there are strong social influences on foraging activity in social insects (Robinson, 2002). Honeybees depend on floral resources (nectar and pollen), to supply individual and colony sustenance. Under normal colony conditions, the forager honeybees are workers with an age over 21 days, when they shift to perform out-colony tasks including food collection (Huang and Robinson, 1996).

The forager can be classified into two categories; persistent foragers which search for the best food resource and the reticent foragers which wait in the beehive until the scout bees return and give them information about the food source by dancing (Van Nest et al., 2016). The reticent bees, in general, range from $40-90 \%$ of the total forager population (Nest and Moore, 2012). Foragers gather information from their hive mates about the nectar availability within the hive (Dreller et al., 1999). There are many environmental factors that can affect foraging activity. The presence of suitable plant resources has a great impact on foraging activity, and forager bees have a preference for some resources over others (Fülöp and Menzel, 2000). Temperature is also one of the most important environmental factors that influence honeybee foraging activity (Blažytė-Čereškienè et al., 2010, Tan et al., 2012). Therefore, it is expected that foraging activity is highly influenced by elevated temperature with pollen foragers (Cooper et al., 1985). In contrast, relative humidity had less effect on flight activity (Joshi and Joshi, 2010).

To evaluate the effect of some local environmental factors, our study was carried out in which the foraging behavior of a colony of Apis melliferain, at the apiary of faculty of Agricultural, located in Agriculture farm at Suez Canal University, was monitored for successive periods of 12 months. Meanwhile, the investigation of the seasonal and diurnal foraging rhythm of honeybees and their abundance under field conditions were also considered.

\section{MATERIALS AND METHOD}

\section{Study Area}

Honeybee foraging behavior of a colony at the apiary of faculty of Agricultural (Figure1), Suez Canal University, Ismailia, Egypt $\left(27.000^{\circ} \mathrm{N} 30.000^{\circ} \mathrm{E}\right)$, was monitored along 48 different days for 12 successive months. The total land area of the study site was about $5 \mathrm{~km}^{2}$, where no other apiary or honeybee hives were existed around the study area.

\section{Observation of Foraging Activity}

Foraging activity was evaluated during the time period of the study except during rainy and windy days loaded with dust. The foraging activity of honeybee workers was estimated, in which number of forager bees were counted periodically once /week for totally 140 minutes from dawn to dusk (in approximate 10 minutes/hr).

The number of bees returning to the hive entrance, assumed that loaded with pollen and nectar, were recorded. In addition, number of the bees that leaving the hive were also recorded. The size of the hive entrance was tightened to control the number of bees leaving or entering the hive, as only one bee can pass from this entrance so it can be counted.

Temperature and humidity were recorded every hour using a thermocouple thermos-hygrometer, besides several weather data (cloudy, clear sky or rainy) and any identifiable variation in the bee behavior. All labors were carefully worked and practice to keep them at the same condition as other colonies at the bee yard.

\footnotetext{
*Corresponding author e-mail: Reem_Mahmoud@science.suez.wdu
} 


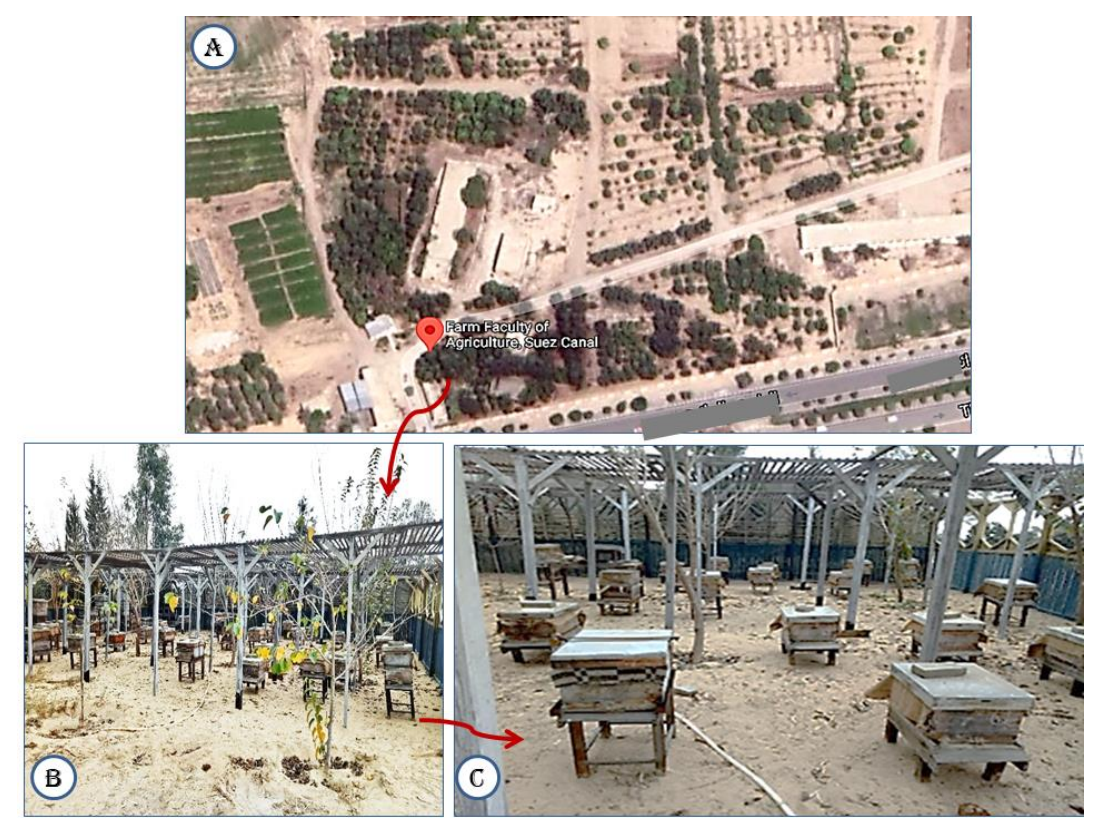

Figure (1): Apiary location at Faculty of Agriculture, Suez Canal University; (A) Location image of Agriculture farm where the apiary is located; (B) the apiary study area, with different wooden honeybees' hives, which is about $25 \mathrm{~m}^{2}$; (C) the wooden honeybee's hives showing the dimension of honeybee's hives and the distance between them.

These practices include supply the Clooney by brood frames when it needed. The full frames of honey were taken off from the hive, in addition to supply bees with suitable food sources overwintering.

\section{Data Analysis}

Data recorded, in means, were statistically analysed, for differences among the measured parameters, using SPSS software (Statistical Package for Social Science, Version 18.0). The results showing differences, with $p \leq 0.05$, are conventionally regarded as statistically significant different. Meanwhile, all data measured were recorded in means \pm standard error $(\mathrm{SE})$.

\section{RESULTS}

The daily activity pattern of honeybees showed negative significant difference $(p \leq 0.002)$ with day temperature from dawn to dusk over months at the time period of the study (Figure 2). However, honeybees' activity pattern fluctuated throughout the day, bees' activity usually initiated at early morning and ended after sunset. In December, honeybee's activity started at early morning $(6: 00 \mathrm{am})$ with a peak of activity recorded at 9:00 h. Another peak took place around 14:00 h. In January and March, bees' activity started almost at 7:00 with a morning peak almost at 11:00 h and afternoon peak at 15:00 h, while in February the first peak started at 10:00 h, while an afternoon peak was recorded at 15:00 h. In April, May and June, the activity started at 6:00 $\mathrm{h}$ with morning peak at 12:00 h and afternoon peak at 16:00 h. Moreover in July, August and September, bee's activity started at 6:00 h too, while activity peaks seemed to be appeared in the morning from 9:00 to $12: 00 \mathrm{~h}$ and with afternoon peak at 17:00 h. Finally, in October and November morning activity peak was recorded 10:00 h to $11: 00 \mathrm{~h}$ with no afternoon peak.

\section{Seasonal Activity Pattern}

Recording honeybees' activity during different season of the study was represented in (Fig. 3). Activity of honeybees showed significant difference $(p \leq 0.001)$ among seasons. Bees recorded a highest activity peak in spring followed by winter, while in autumn the activity decreased and the least activity was observed. A bimodal pattern of honeybees' activity appeared in spring, in which activity increased continuously till reaching the first peak at noon, around 11:00 am, then activity decreased and started to elevate till it reached the second peak at afternoon, around 15:00 pm. In winter there was a backward shifting in honeybee's activity when the first peak of activity increased until it reached its peak at 10:00 am and the second peak at 14:00 pm. In summer, the first peak started earlier around 8:00 am and remain at its peak till 11:00 am, followed by the second daily peak which started around 16:00-18:00 pm. In autumn, there was a monomodal activity pattern in which only one morning peak was recorded and it started around 8:00-11:00 am.

\section{Monthly Abundance}

Monthly abundance of forager bees (Fig.4) changed significantly among different months of the year $\left(\chi^{2}=\right.$ 471.93, $\mathrm{df}=11, p \leq 0.00001)$. Active honeybee numbers increased during the time period of the study in which February recorded the highest value (474 \pm 153 individual/day). However in March significant decrease was recorded with mean number of $397 \pm 130$ individual/day followed by April with mean number of $378 \pm 128$ individual/day. In meanwhile, by December continues decrease. in bees abundance, was recorded with mean number of $237 \pm 77$ individual/day. 


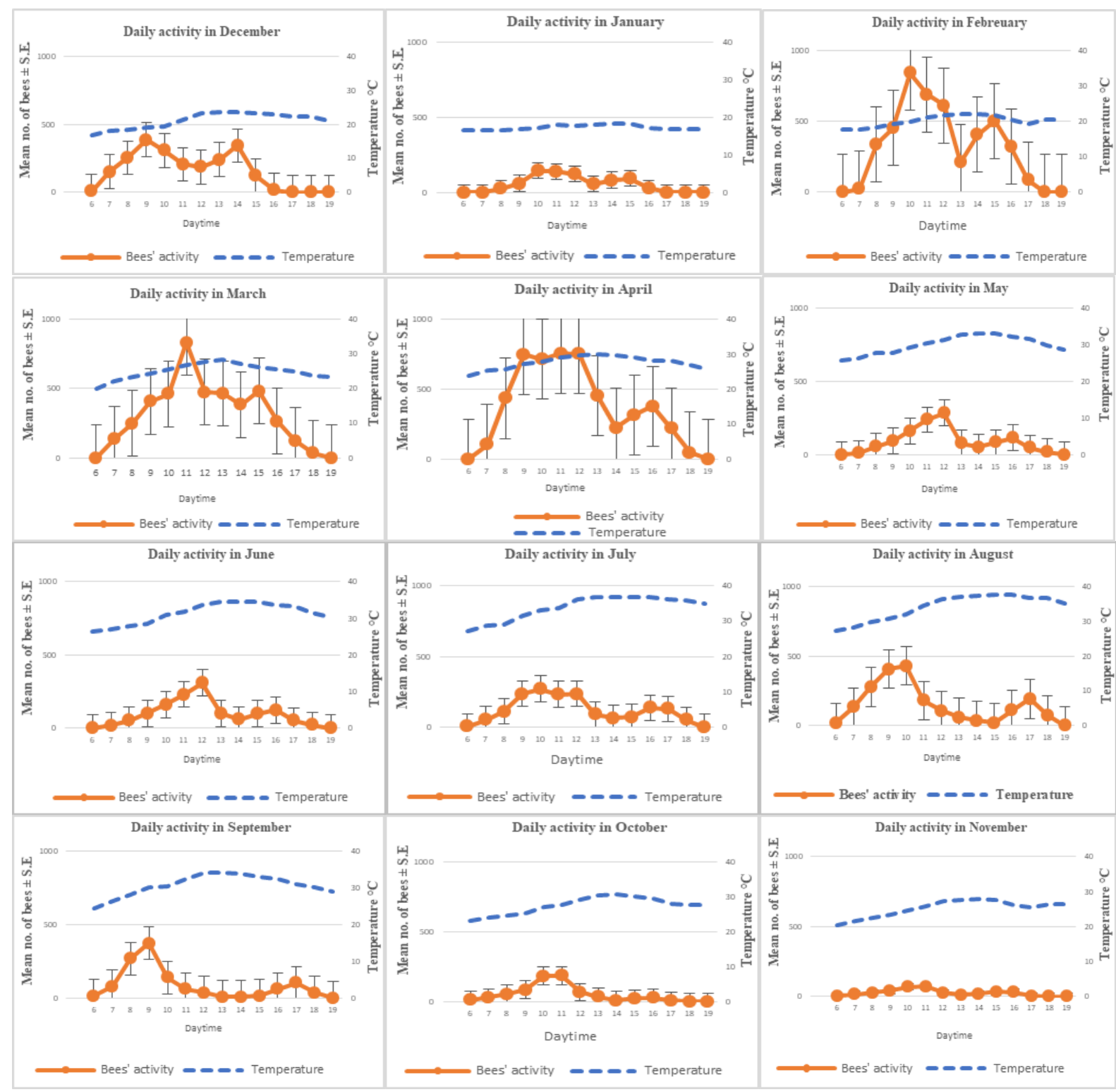

Figure (2): Daily activity rhythm of honeybees, Apis mellifera, during the study period. The bees' numbers are represented in mean \pm S.E.

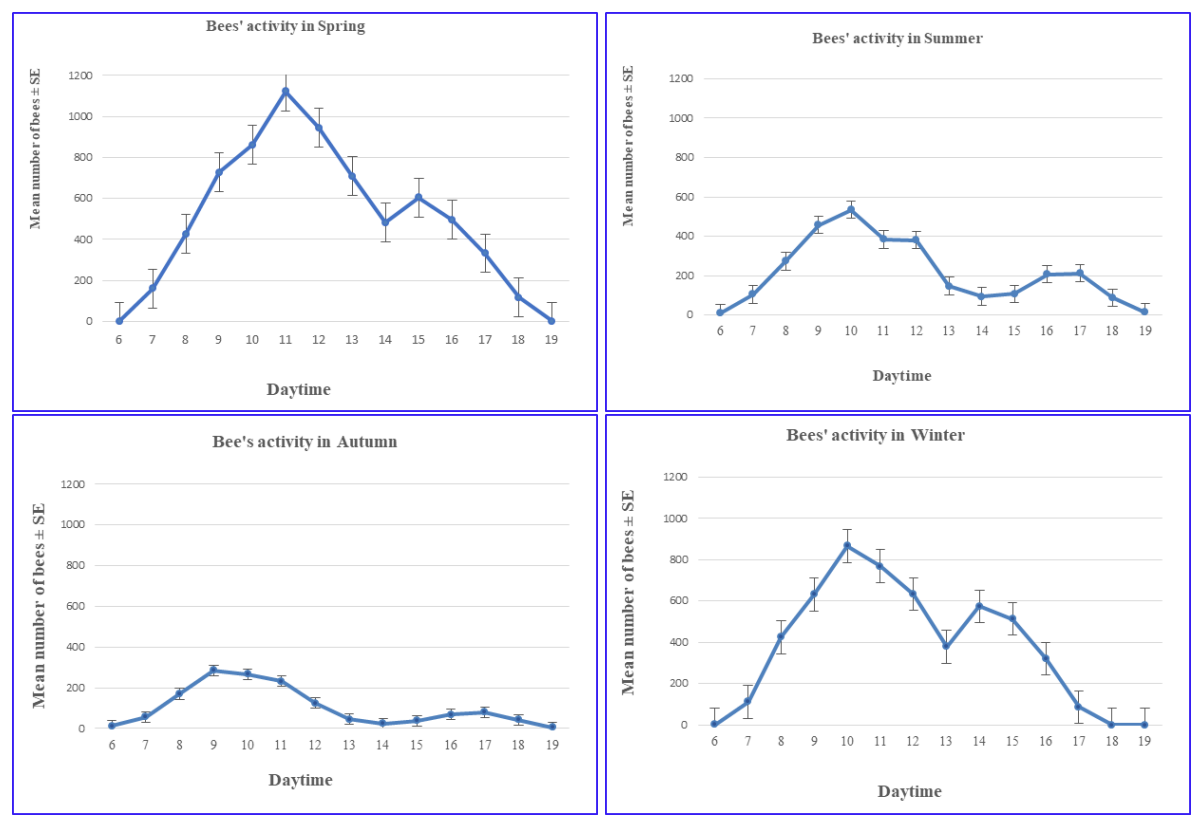

Figure (3): Honeybee's activity pattern in different seasons during the study period, The bees' numbers are represented in mean \pm S.E. 
The abundance decreased during January with mean number of $96 \pm 30$ individual/day and in October with mean number of $85 \pm 30$ individual/day. In November the abundance continued to decrease and recorded 32 \pm 10 individual/day. The other five months showed intermediate abundance as in August where the mean number of active bees was $207 \pm 72$ individual/day, while in September, it recoded $147 \pm 52$ individual/day. In July, less abundance was recorded (126 \pm 42 individual/day) but still higher than in January. In June and May, less abundance were recorded $(117 \pm 43$ and $115 \pm 39$ individual/day, respectively; Figure 4).

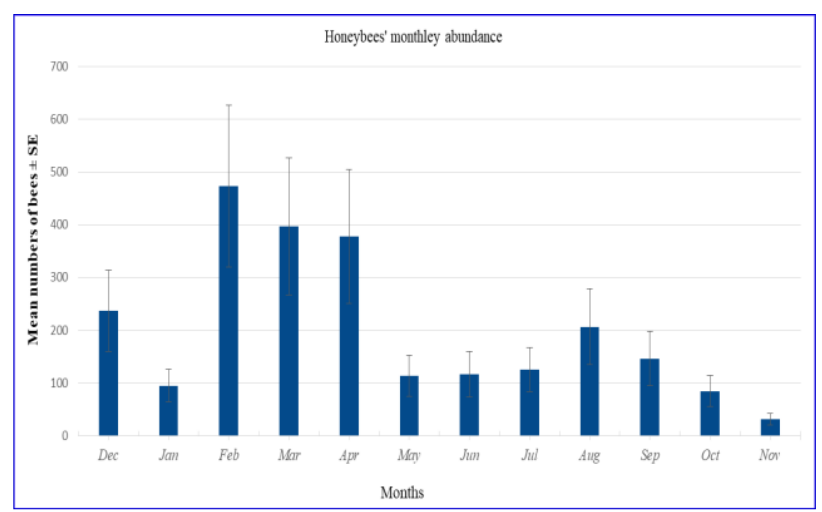

Figure (4): Monthly abundance of honeybee during the study period. Data represented in mean \pm SE.

\section{Seasonal Abundance}

The seasonal abundance of forager bees changed significantly among different seasons $\left(\chi^{2}=303.35, \mathrm{df}=\right.$ $3, \mathrm{p} \leq 0.00001)$, where it increased during Spring followed by Winter. However, in Autumn it recorded the lowest value. During Spring, the average number of honeybees was $498 \pm 94$ individual/day followed by Winter when it was $379 \pm 80$ individual/day, while in Summer it was $215 \pm 45$ individual/day and the least abundance appeared in autumn when it was $103 \pm 26$ individual/day (Figure 5).

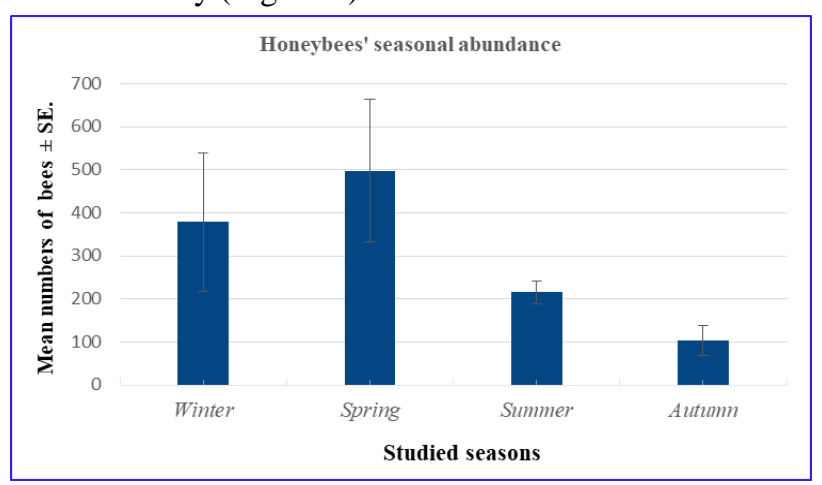

Figure (5): Seasonal abundance of honeybees during the study period. Data represented are in means \pm S.E.

\section{DISCUSSION}

Foraging activity investigation was estimated by counting the mean number of bees returning to hive and leaving hive, which is one of the most traditional ways for measuring foraging activity of honeybees in field (Beekman et al., 2004; Alqarni, 2006; Ali, 2011; Malerbo-Souza, 2011; Abou-Shaara et al., 2013). Our study was carried out to monitor the variation in daily activity and abundance of honeybees across year months and seasons at local site of apiary of faculty of Agricultural, Suez Canal University, Ismailia, Egypt.

Foraging rhythm in the studied field revealed that bees' activity was increased within a window of temperature which is in concurrent with Stone et al., (1999) as well as Klein et al., (2019). The foraging activity of honeybees depends on many factors; Joshi (2010) related the pollinator activity to the temperature of the site. The activity take place, in late hours on the morning (10:00 - 11:00 h) and in afternoon (15:30 $17: 30 \mathrm{~h})$, when temperature is suitable and the weather is warm which is coincided with the result of this study. High temperature at noon is a major reason for the decline in the flights which has been observed in various solitary bee species (Herrera, 1990), in addition to dehydration at high temperature (Pierrot and Schlindwein, 2003; Zohdy and Rahman (2015) and Harano 2020).

Bees adapt the number of visits to nectar secretion rate, Williams (1997) correlates bees' foraging activity with nectar availability, as well as Silva et al., (2013) who relates the foraging rhythms with bees' food availability as they have the ability to remember the time of the day at which the higher food resources are available. Most plants anthesis initiates early in the morning and the flowers present their nectar already with the beginning of anthesis. At noon, general flight activity is reduced, and this associated with the scarcity of food resources. Most flowers that open in the morning are already empty by noon, while sources of nectar do not start nectar production until the afternoon (Bloch et al., 2017).

Honeybees showed high activity in afternoon, which is similar to the result of a study carried by Danka et al., (2006) who found that under environmental conditions, honeybees' foraging activity, in afternoon. is usually high, but it differs from the study of (Blazyte-Cereskiene et al., 2010) who revealed that honeybees' foraging activity diminished in afternoon as air temperature reached $43^{\circ} \mathrm{C}$.

However, for monthly abundance recorded in the current study documented that bee's monthly abundance varies across months, with the highest abundance in February, March, and April. On the other hand, October and November show the lowest activity. The bees' activity had a window of opportunity of ambient temperatures, they forage in temperature range from $20^{\circ} \mathrm{C}$ to $28^{\circ} \mathrm{C}$ as explained by Danka et al., (2006), Kreitlow (2006), Afik (2007) and Honchel (2016). Meanwhile, Joshi (2010) reveled that flight begins at $16^{\circ} \mathrm{C}$ but bees abundance remains low and the number of forager bees increase as temperature increase above $20^{\circ} \mathrm{C}$. Also Tan et al., (2012) reveled that at ambient temperature about $20^{\circ} \mathrm{C}$ the highest activity was recorded, and this is compatible with current study.

Blazyte-Cereskiene et al., (2010) coupled the decrease in honeybee density with the increase in temperature. Elevation of ambient temperature not only 
has direct negative impact on the forager bees but also has indirect effect by its negative impact on the plant flowering, scent and nectar production decline. The decline in flight activity was linked with temperature as discussed by Danka et al., (2006), when temperature is above $30^{\circ} \mathrm{C}$, honeybees remain at their hive entrance ventilating the hives to reduce hive temperatures. The high temperature above $30^{\circ} \mathrm{C}$ reduce floral scent production and emission in addition to nectar secretion in plant which in turn reduce bees' abundance (Petanidou and Smets, 1996, Sagae et al., 2008 ).

In October and November, which smother the most clouds according to the Egyptian weather forecast, the flight activity terminates during rainy and cloudy weather which is similar to the study of Joshi (2010) who revealed that Apis mellifera prefer to be in their hives during rainy and cloudy weather. In general, honeybees have seasonal variation in their seasonal abundance. Spring govern the maximum abundance followed by Winter and Summer, on the other side Autumn had the least honeybee abundance which is fit with the result of Ginsberg (1983) and Wood et al., (2018).

Foraging activity levels over the season closely linked to resource availability and flower abundance over the season, in addition to its correlation with activity levels of pollen collection (Park and Nieh, 2017). Social insects, as honeybees can store food to consume during periods of resource scarcity. Floral resources scarcity for honeybees has been reported predominantly in Summer months of July and August (Couvillon et al., 2014, Scheper et al., 2014). Ginsberg (1983) noticed that in spring most flowers bloomed along roadsides, in cultivated fields or in forest which lead to maximize honeybee foraging activity in this season.

The seasonal foraging pattern was related to foraging distance as revealed by Park (2017), in Spring foraging distances were the shortest while it was greatest during Summer, so activity levels in Spring showed highest level while in Summer it was low. Danner et al., (2016) similarly showed that honeybee foraging distance decreased during the season of food abundance. These studies confirmed that colonies search and forage over wide areas and adjust this foraging in respond to short-term (daily and weekly) and long-term (monthly) fluctuations in resource availability. They also detected that honeybees compensate poor divers landscapes by increasing their foraging range in order to maintain the amount and diversity of the collected pollen (Danner et al., 2017).

Brood production can also affect seasonal foraging activity. Winston, (1987) revealed that during early Spring, the lengthening days and new sources of pollen and nectar stimulate brood rearing. The bees also gather water to regulate temperature and to liquefy thick or granulated honey in the preparation of brood food. Later in the Spring, the population of the colony expands rapidly, and the proportion of young bees increases. As the population increases, the field-worker also increases which is similar to the results of
Schneider (1992) who investigated that pollen collection dominated foraging activity, and that there was a positive correlation between the amount of brood comb in the colonies and the proportion of daily foraging dances (Peso and Barron 2014).

In Autumn, a reduction in the amounts of nectar and pollen coming into the hive causes reduced brood rearing and diminishing population as revealed by Okada et al., (2012). Similarly to Sherman and Visscher, (2002), who reported that colonies they tested in California had lost hive mass in Autumn and gained it in Summer.

For daily activity patterns, a study done by Schneider (1992) recorded that activity patterns, that reflecting the seasonal patterns in the timing of pollen and nectar of Okavango plants, were highly influenced by changes in temperature, relative humidity, and rainfall (Palgrave et al., 2003). Therefore, the significant high occurrence of foraging in warm cooldry season may have resulted from the presence of suitable temperature for honeybee foraging. This coincides with the result of our study, where it showed that the foraging activity in winter reflected a high incidence level. The warm weather, in winter, of Egypt can explain this phenomenon which is suitable for honeybee foraging activity.

\section{REFERENCES}

ABOU-SHAARA, H.F., AL-GHAMDI, A.A., AND MOHAMED, A.A. 2013. Honeybee colonies performance enhance by newly modified beehives. Journal of Apicultural Science 57: 45-57.

AFIK, O. AND SHAFIR, S. 2007. Effect of ambient temperature on crop loading in the honeybee, Apis mellifera (Hymenoptera: Apidae). Entomologia Generalis 29: 135-148.

ALI, M.A.M. 2011. Comparative study for evaluating two honeybee races, Apis mellifera jementica (indigenous race) and Apis mellifera carnica (carniolan race) in brood production, population development and foraging activity under the environmental conditions of the central region of the Kingdom of Saudi Arabia. Annals of Agricultural Sciences 56: 127-134.

ALQARNI, A. 2006. Tolerance of summer temperature in imported and indigenous honeybee Apis mellifera L. races in Central Saudi Arabia. Saudi Journal of Biological Sciences 13: 133-138.

BEEKMAN, M., SUMPTER, D.J.T., SERAPHIDES, N. AND RATNIEKS, F.L.W. 2004. Comparing foraging behaviour of small and large honey-bee colonies by decoding waggle dances made by foragers. Functional Ecology 18: 829-835.

BLAZYTE-CERESKIENE, L., VAITKEVIČIENĖ, G., VENSKUTONYTÉ, S. AND BUDA, V. 2010. Honeybee foraging in spring oilseed rape crops under high ambient temperature conditions. Zemdirbyste 97: 10.

BLOCH, GUY, NOAM BAR-SHAI, YOTAM CYTTER, AND RACHEL GREEN. 2017. Time Is 
Honey: Circadian Clocks of Bees and Flowers and How Their Interactions May Influence Ecological Communities. Philosophical Transactions of the Royal Society B: Biological Sciences. 372(1734).

COOPER, P., M SCHAFFER, W. AND BUCHMANN, S. 1985. Temperature regulation of honeybees (Apis mellifera) foraging in the Sonoran Desert. Journal of Experimental Biology 114: 1-15.

COUVILLON, M.J., SCHÜRCH, R. AND RATNIEKS, F.L.W. 2014. Waggle dance distances as integrative indicators of seasonal foraging challenges. PLOS ONE 9: e93495.

DANKA, R.G., SYLVESTER, H.A. AND BOYKIN, D. 2006. Environmental influences on flight activity of USDA-ARS Russian and Italian stocks of honeybees (Hymenoptera: Apidae) during almond pollination. Journal of Economical Entomology. 99: 1565-1570.

DANNER, N., KELLER, A., HÄRTEL, S. AND STEFFAN-DEWENTER, I. 2017. Honeybee foraging ecology: Season but not landscape diversity shapes the amount and diversity of collected pollen. PLOS ONE 12: e0183716.

DANNER, N., MOLITOR, A.M., SCHIELE, S., HÄRTEL, S. AND STEFFAN-DEWENTER, I. 2016. Season and landscape composition affect pollen foraging distances and habitat use of honeybees. Ecological Applications 26: 1920-1929.

DRELLER, C., PAGE, R.E. AND FONDRK, M.K. 1999. Regulation of Pollen Foraging in honeybee colonies: effects of young brood, stored pollen, and empty space. Behavioral Ecology and Sociobiology 45: 227-233.

FÜLÖP, A. AND MENZEL, R. 2000. Risk-indifferent foraging behaviour in honeybees. Animal Behaviour 60: 657-666.

GINSBERG, H.S. 1983. Foraging ecology of bees in an old field. Ecology 64: 165-175.

HARANO, KEN-ICHI. 2020. Honeybee Colonies Provide Foragers with Costly Fuel to Promote Pollen Collection. Journal of Comparative Physiology. 206(4): 587-595.

HONCHEL, J. AND KRISHNA, S. 2016. Foraging behavior of Apis mellifera in Southwestern Ohio during the late summer months. The Ohio Journal of Science 116: 21-25.

HUANG, Z.-Y. AND ROBINSON, G.E. 1996. Regulation of honeybee division of labor by colony age demography. Behavioral Ecology and Sociobiology 39: 147-158.

JOSHI, N. AND JOSHI, P. 2010. Foraging behaviour of Apis Spp. on apple flowers in a subtropical environment. New York Science Journal 3: 71-76.

KLEIN, SIMON, CRISTIAN PASQUARETTA, XU JIANG HE, ET AL. 2019. Honeybees Increase Their Foraging Performance and Frequency of Pollen Trips through Experience. Scientific Reports. 9(1): 6778.

KREITLOW, K.L. AND TARPY, D.R. 2006. Environmental and genotypic effects on russianhybrid and italian honeybee (Apis mellifera)
(Hymenoptera: Apidae) foraging behavior. Environmental Entomology 35: 1610-1616.

MALERBO-SOUZA, D.T. 2011. The corn pollen as a food source for honeybees. Acta Scientiarum. Agronomy 33: 701-704.

NEST, B.N.V. AND MOORE, D. 2012. Energetically optimal foraging strategy is emergent property of time-keeping behavior in honeybees. Behavioral Ecology 23: 649-65.

OKADA, R., AKAMATSU, T., IWATA, K., IKENO, H., KIMURA, T., OHASHI, M., AONUMA, H. AND ITO, E. 2012. Waggle dance effect: dancing in autumn reduces the mass loss of a honeybee colony. Journal of Experimental Biology. 215: 1633-1641.

PALGRAVE, K.C., DRUMMOND, R.B., MOLL, E.J. AND PALGRAVE, M.C. 2003. Trees of Southern Africa, 3 edition. ed. Struik Pub, Cape Town.

PARK, B. AND NIEH, J.C. 2017. Seasonal trends in honeybee pollen foraging revealed through DNA barcoding of bee-collected pollen. Insectes Sociaux. 64: 425-437.

PESO, MARIANNE, AND ANDREW BARRON. 2014. The Effects of Brood Ester Pheromone on Foraging Behaviour and Colony Growth in Apicultural Settings. Apidologie. 321: 9.

PETANIDOU, T. AND SMETS, E. 1996. Does temperature stress induce nectar secretion in Mediterranean plants? New Phytologist 133: 513518.

ROBINSON, G.E., 2002. Genomics and integrative analyses of division of labor in honeybee colonies. The American Naturalist 160: 160-172.

SAGAE, M., OYAMA-OKUBO, N., ANDO, T., MARCHESI, E. AND NAKAYAMA, M. 2008. Effect of temperature on the floral scent emission and endogenous volatile profile of petunia axillaris. Bioscience, Biotechnology, and Biochemistry 72: 110-5.

SCHEPER, J., REEMER, M., KATS, R. VAN, OZINGA, W.A., LINDEN, G.T.J. VAN DER, SCHAMINÉE, J.H.J., SIEPEL, H. AND KLEIJN, D. 2014. Museum specimens reveal loss of pollen host plants as key factor driving wild bee decline in The Netherlands. Proceedings of the National Academy of Sciences 111: 17552-17557.

SCHNEIDER, S.S. AND MCNALLY, L.C. 1992. Seasonal patterns of foraging activity in colonies of the African honeybee, Apis mellifera scutellata, in Africa. Insectes Sociaux 39: 181-193.

SEELEY, T.D. 1995. The wisdom of the hive: the social physiology of honeybee colonies. Harvard University Press, Cambridge, Mass.

SHERMAN, G. AND VISSCHER, P.K. 2002. Honeybee colonies achieve fitness through dancing. Nature 419: 920-922.

STONE, G.N., GILBERT, F., WILLMER, PAT., POTTS, S., SEMIDA, F. AND ZALAT, SAMY. 1999. Windows of opportunity and the temporal structuring of foraging activity in a desert solitary 
bee: Foraging responses of a desert bee. Ecological Entomology 24: 208-221.

TAN, K., YANG, S., WANG, Z.-W., RADLOFF, S.E. AND OLDROYD, B.P. 2012. Differences in foraging and broodnest temperature in the honeybees Apis cerana and A. mellifera. Apidologie 43: 618-623.

VAN NEST, B.N., WAGNER, A.E., HOBBS, C.N. AND MOORE, D. 2016. Dance floor clustering: food-anticipatory behavior in persistent and reticent honeybee foragers. Behavioral Ecology and Sociobiology 70: 1961-1973.
WINSTON, M.L. 1987. The biology of the honeybee Harvard University Press, Cambridge, Mass.

WOOD, T.J., KAPLAN, I. AND SZENDREI, Z. 2018. Wild bee pollen diets reveal patterns of seasonal foraging resources for honeybees. Frontiers in Ecology and Evolution 6: 1-12.

ZOHDY, N., ABDEL RAHMAN, K., AMER, N. (2015). Effect of temperature on egg development and life table of Chrotogonus homalodemus (Blanchard, 1836) (Orthoptera: Pyrgomorphidae)', Catrina: The International Journal of Environmental Sciences, 10(1), pp. 1-9. doi: 10.12816/0010692

\section{ايقاع سلوك البحث عن المؤن الغذائية لنحل العسل ابيز ميليفيرا في محافظة الاسماعيلية ـ مصر}

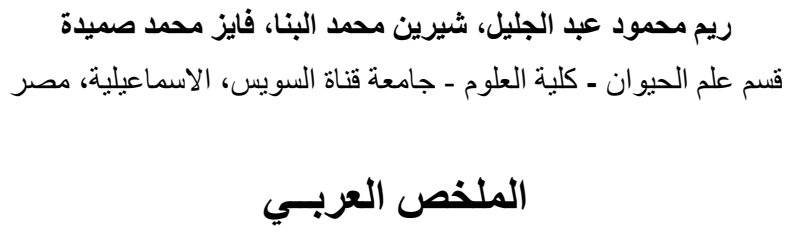

يعتبر نحل العسل من أكثر الحشرات النافعة على وجة الأرض؛ فلقد أثبت علميا مدى دقة قدرته على التواصل و تحديد الاتجاهات

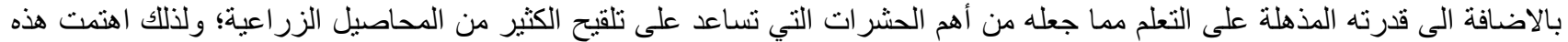

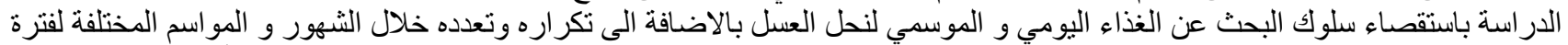

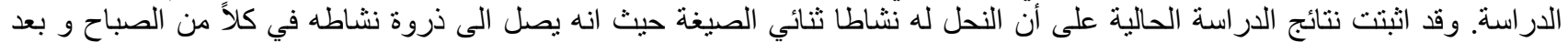

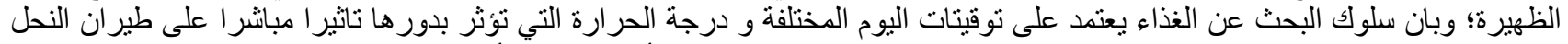

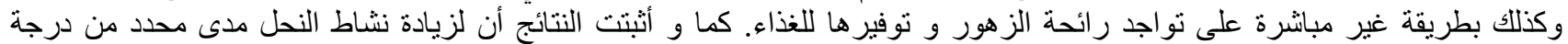

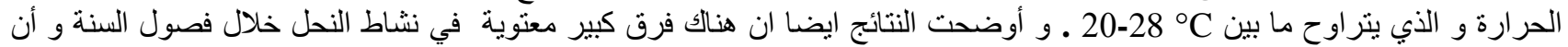
فصل الربيع هو افضل الفصلول لنثاط نحل العنل. 